\title{
Moringa oleifera: an alternative forage of multiple uses for the Brazilian semiarid
}

\section{Moringa oleifera: uma alternativa forrageira de múltiplos usos para o semiárido brasileiro}

\author{
Karen Luanna Marinho CATUNDA ${ }^{1 *}$; Emerson Moreira de Aguiar²; Valdir LIMA JÚNIOR ${ }^{2}$; \\ Margareth Maria Teles REGO²; Adriano Henrique do Nascimento RANGEL ${ }^{2}$
}

${ }^{1}$ Autor para correspondência, Mestre em Produção Animal, Mestre em Produção Animal; UFRN; Laboratório de Nutrição Animal; Campus Universitário Lagoa Nova, CEP 59078-970 | Natal/RN - Brasil. zootecnistakaren@hotmail.com

${ }^{2}$ Doutores em Zootecnia, UFRN, Natal, Rio Grande do Norte, Brasil.

Recebido em: 04-12-2014; Aceito em: 19-06-2017

\begin{abstract}
Moringa oleifera is a medium-sized, fast-growing tree species native to India, which adapts to a wide range of soils and is tolerant to drought. Its importance for human and animal food is due to its nutritive characteristics, having high levels of crude protein, vitamins, minerals and insignificant amounts of antinutritional factors in its leaves. Furthermore, this plant has several other uses that are popularly recognized and corroborated by the scientific community, such as medicinal application, treatment of turbid waters, oil production and live fencing. Due to its climate adaptability, forage potential and various uses, moringa has been shown to be a viable alternative to be used in the Brazilian semiarid. Notwithstanding, there is still little research leading to better information on the use of this plant in the semiarid region and that can subsidize breeders and researchers for its propagation. This review was elaborated with the aim of discussing information to improve the use of Moringa oleifera as an alternative forage of multiple uses for the Brazilian semiarid.
\end{abstract}

Additional keywords: drought; forage; nutritive value; tree species; water clarification.

\section{Resumo}

A Moringa oleifera é uma espécie arbórea de médio porte, nativa da Índia, de crescimento rápido que se adapta a uma ampla faixa de solos além de ser tolerante à seca. Sua importância para alimentação humana e animal é devida as características nutricionais, possuindo em suas folhas elevados teores de proteína bruta, vitaminas, minerais e insignificantes quantidades de fatores antinutricionais. Além disso, esta planta possui diversos outros usos que são reconhecidos por populares e corroborados pela comunidade científica, como exemplo: medicinal, tratamento de águas turvas, produção de óleo e formação de cerca viva. Diante da adaptabilidade as condições do clima, do potencial forrageiro e de seus diversos usos, a moringa tem se mostrado uma alternativa viável para ser utilizada na região do semiárido brasileiro. Entretanto, verifica-se que ainda são escassas as pesquisas que conduzam a melhores informações quanto à utilização desta planta no semiárido e que possam subsidiar criadores e pesquisadores para sua propagação. Esta revisão foi elaborada com objetivo de discorrer sobre informações para aperfeiçoar o uso da Moringa oleifera como alternativa forrageira de múltiplos usos para o semiárido brasileiro.

Palavras-chave adicionais: arbórea; clarificação de água; forragem; seca; valor nutritivo.

\section{Introduction}

Moringa oleifera Lam (synonym: Moringa pterygosperma Gaertner), a plant belonging to the family Moringaceae, is native to India and adapts to a wide range of climatic conditions. In Europe and Africa, it is grown for multiple uses, and its leaves, flowers, fruits and seed oil are used in human food, as well as its branches and leaves are used as fodder. It is also used for medicinal applications, live fencing and windbreaks, and the extract from its seeds is used in the treatment of turbid waters (Bakke et al., 2010).

Moringa has nutritive characteristics favorable to ruminant feeding, since it has high levels of crude protein, vitamins, minerals and insignificant quantities of antinutritional factors in its leaves, in addition to high palatability and digestibility, characterizing this species as a high quality forage (Bakke et al., 2010).

This plant has been highlighted by several other reasons: rapid growth, reaching the forage cutting period at six months; flexible stems; easy handling for cutting; no need for agricultural inputs or advanced technology during planting; pest resistance and absence of integumentary and physiological dormancy in the seeds.

For Almeida et al. (1999), moringa is a foraging tree of great importance for the Brazilian semiarid due to its capacity for survival and production in areas 
of low soil moisture, in addition to its tolerance to high air temperatures, high evaporation and large variations in precipitation. However, in the Brazilian semiarid, there is little information on the use of this plant.

In view of the above, this review was carried out with the aim of presenting information to improve the use of Moringa oleifera as an alternative forage of multiple uses for the Brazilian semiarid.

\section{Origin and Agronomic Characteristics}

Moringa oleifera is a medium-sized tree, known in Brazil as "quiabo-de-quina", "lírio-branco" (or white lily), "baqueta" (or "drumstick", because of the shape of its pod) and "rábano" (or radish, in view of the taste of its roots, resembling radish). This plant belongs to the kingdom Plantae, division Magnoliophyta, class Magnoliopsida, order Brassicales, being the most popular species and belonging to the monogenic family Moringaceae of the genus Moringa.

Moringa originates from the Agra and Oudh region of northwestern India, south of the Himalayan mountains, being widely cultivated in Asia, Africa, and other tropical regions of the world, such as Brazil (Okuda et al., 1999). In Central America, it was introduced in 1920 as an ornamental plant, being also used for live fencing (Foidl et al., 1999).

The introduction of moringa in Brazil took place in 1950, probably through the Department of Agriculture of the State of Maranhão, who imported it from the Philippines. Its presentation to the scientific milieu occurred in 1982, through Dr. Warwick Estevam Kerr, resulting in the planting of 25,000 seedlings by university students at workers' homes in the State of Maranhão, aiming at the nutritive properties of its leaves (Kerr \& Silva, 1999).

Moringa is a perennial tropical plant of easy production, management and propagation (sexually or asexually), requiring no special treatments or large amounts of nutrients in the soil, not even water after planting (Foidl et al., 1999).

This fast-growing plant reaches up to $15 \mathrm{me}$ ters in height (Ferreira et al., 2008) and has a short trunk with $25 \mathrm{~cm}$ thickness (Sánchez et al., 2006a). According to Pérez et al. (2010), it is short-lived and can live for up to 20 years, with annual varieties found in India. It reaches 5.0 meters in height in little more than a year and has a straight stem of fragile, low-density light wood $\left(0.19 \mathrm{~g} / \mathrm{cm}^{3}\right)$ (Morton, 1991).

Ramachandran et al. (1980) argued that moringa is very resistant to drought, being grown in arid and semiarid regions of India, Pakistan, Afghanistan, Saudi Arabia and East Africa, with rainfall around 300 $\mathrm{mm}$ per year. According to Sánchez et al. (2006a), moringa tolerates an annual precipitation of 500 to $1,500 \mathrm{~mm}$.

This tree provides high amounts of nutrients to the soil, as well as protects it from external factors such as erosion, drying and high temperature (Morton, 1991). The soil $\mathrm{pH}$ range for moringa growth is in the range from 5 to 9 , but the tree does not adapt to poorly drained and heavy clayey soils, preferring neutral or slightly acidic soils (Sánchez et al., 2006a).

According to Bakke et al. (2010), moringa propagates by means of seeds, seedlings or cuttings, showing good germination rate when freshly harvested under conditions of adequate moisture. As an adult, it reaches an annual production of 3 to 5 tons of seeds per hectare (Morton, 1991).

\section{Flowers, fruits and leaves}

The flowers are bisexual, with white petals and yellow stamens (Falasca \& Barnabé, 2008). In some regions, moringa blooms only once a year, but its blooming can occur twice a year, as in the case of Caribbean countries such as Cuba (Pérez et al., 2010). The flowers are pollinated by bees, as well as by other insects and some birds (Morton, 1991).

The fruit (pod) is capsule-shaped, containing round seeds of dark brown color with three whitish wings that facilitate wind dispersal under natural conditions (Morton, 1991).

The leaves of 3 to $5 \mathrm{~cm}$ in length are composite, alternate and arranged in groups of leaflets with three to five pairs arranged on a main petiole (Sánchez et al., 2006a; Pérez et al., 2010).

According to Kerr \& Silva (1999), the leaves are rich in phosphorus, calcium, iron, and vitamins $C$ and $A$, the latter being present in about $23,000 \mathrm{IU}$ per $100 \mathrm{~g}$ of mature leaves, a higher content when compared to traditional plants such as broccoli, carrots, cabbage, spinach and lettuce, which contain, respectively, 5,000, 3,700, 2,200, 1,900 and 1,000 IU vitamin A. Withal, the leaves are an important source of protein, with $27 \%$ protein in the dry matter (Becker, 1995).

Its leaves have been shown to be excellent nutritional sources, providing more vitamin A than carrots, more calcium than milk, more iron than spinach, more vitamin $\mathrm{C}$ than oranges and more potassium than bananas (Fahey, 2005).

\section{Multiple Uses}

\section{Food and medicinal application}

In Europe and Africa, moringa is cultivated for multiple uses; its leaves, flowers, fruits and seeds (crude and roasted) are used as feed and its branches and leaves are used as fresh or dehydrated forage (Bakke et al., 2010).

Moreover, since its leaves have high nutritive potential, they are used to combat child malnutrition (Morton, 1991). The seeds can also be used as an excellent substitute food for vegetables that are generally poor in sulfur-containing aminoacids (Ferreira et al., 2008).

The extracts of all parts of this plant have pharmacological properties that are popularly recognized and corroborated by the scientific community, such as production of antibiotic oils and growth hor- 
mone. However, the most cited medicinal use of moringa is for skin diseases, digestive system diseases and joint impairments (Ferreira et al., 2008).

\section{Water treatment}

Moreover, one of the most reported applications of moringa is the use of its seed extract in the treatment of turbid waters as a clarifying agent and as a natural coagulant, efficiently replacing aluminum salts (Gallão et al., 2006).

The commonly used method consists in placing raw water in contact with 2 to 3 ground seeds for each liter of water in a container; depending on the turbidity, after 2 hours of permanence the supernatant is withdrawn, and then this water is used for consumption (Mendes \& Coelho, 2007). Studies have shown that the percentage of turbidity removal is 80 to $99 \%$ (Okuda et al., 1999).

Currently, the moringa crop has been spread throughout the Brazilian northeastern semiarid, due to its application in water treatment for domestic use (Gallão et al., 2006). In the state of Ceará, programs were created to distribute kits with moringa seeds with instructions for use to rural populations, aiming to offer a simple and renewable solution to the deleterious effect of drinking water shortages, improving the quality of life, helping to reduce child mortality and collaborating with the region's sustainable development (Ferreira et al., 2008).

\section{Distinct uses}

Falasca \& Barnabé (2008), belonging to the Colombian Corporation of Ecology, Agriculture and Livestock Ltd., recommend moringa for biodiesel production, since the seeds contain 31 to $47 \%$ oil. This light yellow oil is highly resistant to oxidative rancidification, which may explain its various industrial uses (Tsaknis et al., 1999).

For Oliveira et al. (2012), based on the results of the experiment carried out in the northeast of Brazil, the moringa seed produces a good quantity of oil with adequate physicochemical characteristics and within the standards to be used as raw material in the transesterification to obtain biodiesel. The average oil content found in moringa seeds was $40 \%$, with an $83.68 \%$ yield in biodiesel.

Moringa is still used in park ornamentation, live fencing, windbreaks, green manure and, furthermore, avoiding soil erosion in areas with intense periods of drought and high winds (Fugliee, 2000).

Foidl et al. (2001) found that the extract of moringa leaves extracted with $80 \%$ ethanol can be used to produce an effective hormone for the development of sugarcane roots and in the growth of plants, increasing the yield of onion, pepper, soybean, corn, sorghum, coffee and melon crops from 25 to $30 \%$.

As can be seen, moringa is a multipurpose plant, since it is also used to produce cosmetics, tablets, dragees, syrups, emulsions and creams, glues, paper, paints and others (Pérez et al., 2010).

\section{Moringa in Animal Feeding}

\section{Forage production}

Sánchez et al. (2006a) carried out an experiment analyzing the effects of different planting densities (250,000, 500,000 and 750,000 plants/ha) and cutting frequencies (45, 60 and 75 days) in the biomass production of Moringa oleifera obtained from Nicaragua, and found a higher yield at 75 days for all densities analyzed. The density of 750,000 plants/ha produced the highest yield of fresh matter and dry matter, of 88.0 and 18.9 t ha/year, respectively.

According to Foidl et al. (1999), the use of moringa as fodder occurs at intervals of 35 to 45 days, when its sprouts reach 1.2 to $1.5 \mathrm{~m}$, depending on the crop management conditions. After being ground, the cut material (leaves, fruits and twigs) can be supplied fresh to the animals after an adaptation period, in which the forage should be mixed with other foods to which the animals are already adapted.

In an experiment with moringa for sheep feeding, Sánchez et al. (2006a) used the distance of 5 $\mathrm{cm}$ between plants and $40 \mathrm{~cm}$ between rows, planted at $1 \mathrm{~cm}$ depth, with cutting at 45 days of age at a height of $25 \mathrm{~cm}$ from the ground. The authors of this experiment concluded that an intensive production of moringa biomass can be achieved with a density of 50 to 75 plants per square meter and cutting every 75 days.

\section{Nutritive potential}

Moringa leaves have all the essential aminoacids, including aminoacids containing sulfur at a higher level than recommended by the Food and Agriculture Organization-FAO, with patterns similar to those of soybean seeds.

When analyzing the seed meal composition, Oliveira et al. (1999) found high contents of essential aminoacids, except for lysine (15.3 g/kg protein), threonine (30.8 $\mathrm{g} / \mathrm{kg}$ protein) and valine $(43.5 \mathrm{~g} / \mathrm{kg}$ protein).

In turn, when analyzing the centesimal composition of moringa seeds, Oliveira et al. (1999) and Abdulkarim et al. (2005) reported high levels of total proteins (332.5, $383.0 \mathrm{~g} / \mathrm{kg} \mathrm{DM})$, lipids (412.0, 308.0 $\mathrm{g} / \mathrm{kg} \mathrm{DM})$, carbohydrates (211.2, $165.0 \mathrm{~g} / \mathrm{kg} \mathrm{DM})$ and ash $(44.3,45.0 \mathrm{~g} / \mathrm{kg} \mathrm{DM}$, respectively). In fact, the total protein content found by Abdulkarim et al. (2005) turned out to be larger than that of some important legume seeds with respect to human nutrition.

Melo (2012) analyzed the nutritive value of moringa hays with different cutting ages and found the following values for the chemical composition of hay at 28 and 49 days of cutting, respectively: 91.33 and $92.88 \%$ dry matter; 12.01 and $10.49 \%$ mineral matter; 25.19 and $21.27 \%$ crude protein; 3.63 and $3.91 \%$ ethereal extract; 59.16 and $64.32 \%$ total carbohydrates; 45.84 and $50.04 \%$ neutral detergent fiber; 28.33 and $34.10 \%$ acid detergent fiber; 59.95 and $61.01 \%$ total digestible nutrients. 
Garcia et al. (2006) evaluated the chemical composition of six non-leguminous species (Azadirachta indica, Cnidoscolus aconitifolius, Ficus carica, Moringa oleifera, Morusalba and Trichantera gigantea) in Trujillo, Venezuela, among which Moringa oleifera presented higher concentrations of $\mathrm{K}$ and $\mathrm{Na}$ (2.65 and $0.24 \%$, respectively), as well as higher contents of soluble carbohydrates $(24.1 \%)$ and ash $(25.8 \%)$ in relation to the others.

Regarding antinutritional factors, whose consumption may affect animal productivity and health, moringa leaves present insignificant amounts of phenols $(2.7 \%)$, tannins $(1.4 \%)$ and saponins $(1.2 \%)$, similar to those found in soy-based foods (Makkar \& Becker, 1996). At these concentrations, they do not produce any adverse effects or toxicity when ingested by ruminants. The leaves also present low amounts of phytates $(2.10 \%)$ and absence of trypsin, lectins and amylase inhibitors, cyanogenic glycosides and glucosinolates (Makkar \& Becker, 1997). The latter interfere in the digestion and absorption of nutrients when found in plants, thus reducing food efficiency.

Phytate levels are higher in the seed samples than in the vegetative parts of the plant. This factor can reduce the bioavailability of minerals (particularly $\mathrm{Zn}^{2+}$ and $\mathrm{Ca}^{2+}$ ) in monogastric animals when present in a range of $1 \%$ to $6 \%$ phytate (Thompson, 1993). However, in samples extracted with $80 \%$ ethanol, tannins were not detected and phenol contents were very low $(1.6 \%)$, since these are soluble in aqueous organic solvents such as ethanol, methanol, acetone, etc. (Makkar \& Singh, 1992).

Foidl et al. (1999) point out that there is a need for an adaptation period of the moringa with other foods at the beginning, however the fodder composed only of moringa leaves can be used both as a protein complement and as a complete feed substitute for animals.

\section{Experiments with animals}

According to Foidl et al. (1999), the consumption of green matter of moringa can reach 27 $\mathrm{kg} / \mathrm{animal} /$ day and maintain a stable production of lactating cows, while its use in feeding can reduce costs by up to $10 \%$ when compared to animals supplemented with traditional concentrates.

In a survey carried out in Nicaragua with Creole cows, the following treatments were used: Brachiaria brizantha hay ad libitum not supplemented or supplemented with $2 \mathrm{~kg}$ or $3 \mathrm{~kg}$ of dry matter of moringa leaves. Moringa supplementation increased $(P<0.05)$ dry matter intake to $8.5 ; 10.2$ and $11.0 \mathrm{~kg} \mathrm{day}^{-1}$ and milk production to $3.1 ; 4.9$ and $5.1 \mathrm{~kg} \mathrm{day}^{-1}$ for Brachiaria brizantha hay alone and supplemented with $2 \mathrm{~kg}$ and $3 \mathrm{~kg}$ of dry matter of moringa, respectively. Milk fat, total solids and crude protein and organoleptic characteristics (smell, taste and color) were not significantly different between diets. The coefficients of ap- parent digestibility of dry matter, organic matter, crude protein, neutral detergent fiber and acid detergent fiber increased $(P<0.05)$ in the diets supplemented with moringa compared to $B$. brizantha hay alone (Sánchez et al., 2006b).

Studies also found that when the cottonseed cake was replaced with moringa leaf meal at 10,20 or $30 \%$ dry matter, the milk production in cows increased significantly by $0.8 ; 0.9$ and $1.4 \mathrm{~kg} \mathrm{cow}^{-1}$ day $^{-1}$, respectively. This substitution had no effect on the chemical composition of the milk (Sarwatt et al., 2004).

The studies of Pérez et al. (2010), in the center of Sinaloa, Mexico, suggest moringa as an alternative forage with high protein content for sheep feeding, due to its adaptability to the climate and low production cost, presenting $70.5 \%$ dry matter digestibility and $65.5 \%$ apparent protein digestibility. Gebregiorgis et al. (2012), analyzing the consumption of low quality Rhodes grass hay supplemented with increasing levels of dry leaves of moringa $(0,150,300$ and $450 \mathrm{~g})$ in sheep in Ethiopia, obtained increases in dry matter, organic matter and crude protein intake, weight gain $\left(-13.3, \quad 40.2, \quad 79.1\right.$ and $110.1 \mathrm{~g} \mathrm{head}^{-1}$ day $\left.^{-1}\right)$ and apparent CP digestibility with the inclusion of increasing levels of supplementation with moringa leaves, respectively. Therefore, moringa can serve as a protein supplement during the dry season in sheep production systems. Moyo et al. (2012), in an experiment with crossbred $X$ hosa lop-eared goats, used a basal diet with native pasture grass hay ad libitum and wheat bran (200 $\left.\mathrm{g} \mathrm{day}^{-1}\right)$ in three treatments: basal diet alone; basal diet with sunflower cake and basal diet with dry leaves of moringa. The authors obtained results for crude protein of 14.08; 23.2 and $23.75 \%$, mean daily weight gain of 43.3 ; 101.31 and $103.3 \mathrm{~g}$, feed intake of $404.5 ; 491.5$ and $490.75 \mathrm{~g}$ and warm carcass weight of $8.59 ; 10.48$ and $10.34 \mathrm{~kg}$, respectively, for treatments with basal diet alone; basal diet with sunflower cake and basal diet with dry leaves of moringa.

In a study evaluating the nutritive effect of fresh leaves of Moringa oleifera as complementary food in the production and quality of eggs of Rhode Island Red chickens in Yucatán, Mexico, Mohammed et al. (2011) obtained satisfactory results with higher egg-laying rates, lower feed intake and a better feed conversion rate, as well as larger yolk size and better yolk color for the treatment with ration supplemented with moringa leaves ad libitum when compared to chickens fed only with control ration ad libitum.

In Brazil, there are still few studies regarding the inclusion of Moringa oleifera in animal feeding. Currently, some research on the consumption, digestibility, degradability, ingestive behavior and limitations of moringa use are being developed in order to obtain information to improve the use of moringa as an alternative source of animal feed. However, no scientific data has been published so far regarding these subjects in the Brazilian semiarid. 


\section{Conclusions}

Based on the reviewed literature, it was possible to emphasize that Moringa oleifera is a plant with multiple uses for the human being, since virtually all its parts present numerous possibilities of use. At the same time, the nutritive characteristics of moringa make this plant an excellent option to be used as fodder during the dry season in semiarid regions.

\section{References}

Abdulkarim SM, Long K, Lai OM, Muhammad SKS, Ghazali HM (2005) Some physico-chemical properties of Moringa oleifera seed oil extracted using solvent and aqueous enzymatic methods. Food Chemistry 93(2):253-263.

Almeida VM, Souto JS, Araújo LVC, Pereira Filho JM, Santos RV (1999) Composição químicabromatológica da Moringa (Moringa oleífera Lam.) no semiárido paraibano. In: Congresso Brasileiro de Medicina Veterinária, Campo Grande, (26).

Bakke IA, Souto JS, Souto PC (2010) Características de crescimento e valor forrageiro da moringa (Moringa oleífera Lam.) submetida a diferentes adubos orgânicos e intervalos de corte. Engenharia Ambiental: Pesquisa e Tecnologia 7(2):133-144.

Becker, K (1995) Studies on utilization of Moringa oleífera leaves as animal feed. Institute for Animal Production in the Tropics and Subtropics. University of Hohenheim, Stuttgart. 15p.

Fahey JW (2005) Moringa oleifera: A Review of the medical Evidence for Its Nutritional Therapeutic, and Prophylactic Properties. Trees for Life Journal 1(5):1-15 .

Falasca S, Bernabé MA (2008) Potenciales usos y delimitación del área de cultivo de Moringa oleifera em Argentina. Revista Virtual de Redesma 1(1):1-16.

Ferreira PMP, Farias DF, Oliveira JTA, Carvalho AFUC (2008) Moringa oleifera: bioactive compounds and nutritional potential. Revista de Nutrição 21(4):431-437 .

Foidl N, Makkar HPS, Becker K (2001) The Potential of Moringa oleifera for agricultural and industrial uses. Procedings of the 1th Workshop What Development Potential for Moringa Products? 20p. Available at $<$ https://miracletrees.org/moringa-doc/the_potential_ of_moringa_oleifera_for_agricultural_and_industrial_ uses.pdf $>>$ (accessed mar 09 2014).

Foidl N, Mayorga L, Vásquez W (1999) Utilización del Marango (Moringa oleifera) como forraje fresco para el ganado. FAO- Agroforestería para la Producción Animal en América Latina 1(143):341.
Fugliee L (2000) Se estudian nuevos usos del marango en Nicaragua. EDN 1(68):1-8.

Gallão Al, Damasceno LF, Brito ES (2006) Avaliação química e estrutural da semente de moringa. Revista Ciência Agronômica 37(1):106-109.

García DE, Medina MG, Domínguez C, Baldizán A, Humbría J, Cova L (2006) Evaluación química de especies no leguminosas con potencial forrajero en el estado Trujillo, Venezuela. Zootecnia Tropical 4(4):401-415.

Gebregiorgis F, Negesse T, Nurfeta A (2012) Feed intake and utilization in sheep fed graded levels of dried moringa (Moringa stenopetala) leaf as a supplement to Rhodes grass hay. Tropical Animal Health and Production.44(3):511-517.

Kerr WE, Silva AR (1999) Moringa: uma nova hortaliça para o Brasil. 1.ed. Uberlândia: Minas Gerais: UFU/DIRIU. 95p.

Makkar HPS, Becker K (1997) Nutrients and antiquality factors in different morphological parts of the Moringa oleifera tree. Journal of Agricultural Science 128(3):311-322.

Makkar HPS, Becker K (1996) Nutrional value and antinutrional components of whole and ethanol extracted Moringa oleifera leaves. Animal Feed Science Technology 63(1):211-228.

Makkar HPS, Singh B (1992) Detannification of oak (Quercus incana) leaves: treatments and their optimization. Animal Feed Science Technology 36(1):113$-127$.

Melo SSNS (2012) Consumo e digestibilidade aparente de fenos de Moringa oleífera Lam. com quatro diferentes idades de rebrota. UFRN (Dissertação de Mestrado em Produção Animal).

Mendes F, Coelho N (2007) Estudo do uso da Moringa oleifera para remoção de prata e manganês em águas. Horizonte Científico 1(1):1-18.

Mohammed KAEF, Franco LS, Ricalde RS, Sanchez JFS (2011) The nutritional effect of Moringa oleifera fresh leaves as feed supplement on Rhode Island Red hen egg production and quality. Tropical Animal Health and Production 44(5):1035-1040.

Morton JF (1991) The horseradish tree, Moringa pterygosperma (Moringaceae): a boon to arid lands. Economic Botany 45(3):318-333.

Moyo B, Masika PJ, Muchenje V (2012) Effect of supplementing crossbred Xhosa lop-eared goat castrates with Moringa oleifera leaves on growth performance, carcass and non-carcass characteristics. Tropical Animal Health and Production 44(4):801-809. 
Okuda T, Baes AU, Nishijima W, Okada M (1999) Improvement of extraction method of coagulation active components from Moringa oleífera seed. Water Resource 33(15):3373-3378.

Oliveira DSX, Fonseca DS, Farias PN, Bezerra VS, Pinto CHC, Souza LD, Santos AGD, Matias LGO (2012) Obtenção do biodiesel através da transesterificação do óleo de Moringa oleífera Lam. Revista Holos 1(28):49-61.

Oliveira JTA, Silveira SB, Vasconcelos KM, Cavada BS, Moreira RA (1999) Compositional and nutritional attributes of seeds from the multiple purpose tree Moringa oleifera Lamarck. Journal of the Science of Food and Agriculture 79(6):815-820.

Pérez A, Sánchez T, Armengol N, Reyes F (2010) Características y potencialidades de Moringa oleifera Lamark: una alternativa para la alimentación animal. Pastos y Forrajes 33(4):1-16.

Ramachandran C, Peter KV, Gopalakrishnan PK (1980) Drumstick (Moringa oleifera): A multipurpose Indian vegetable. Economic Botany 34(3):276-283.
Sánchez NR, Ledin S, Ledin I (2006a) Biomass production and chemical composition of Moringa oleifera under different management regimes in Nicaragua. Agroforestry Systems 66(3):231-242.

Sánchez NR, Sporndly E, Ledin I (2006b) Effect of feeding different levels of foliage of Moringa oleifera to creole dairy cows on intake, digestibility, milk production and composition. Livestock Science 101(1-3): 24-31.

Sarwatt SV, Milang'ha MS, Lekule FP, Madalla N (2004) Moringa oleifera and cottonseed cake as supplements for smallholder dairy cows fed Napier grass. Livestock Research for Rural Development 16(6).

Thompson LU (1993) Potential health benefits and problems associated with antinutrients with foods. Food Research International 26(2):131-149.

Tsaknis J, Lalas S, Gergis V, Dourtoglou V, Spiliot V (1999) Characterization of Moringa oleifera variety Mbololo seed oil of Kenya. Journal of Agricultural and Food Chemistry 47(11):4495-4499. 